\title{
The Enzymes of Ammonia Assimilation and their Control in Members of the Genus Erwinia
}

\author{
By D. PULMAN AND B. JOHNSON \\ Department of Microbiology, The Medical School, The University, \\ Newcastle upon Tyne NE1 $7 R U$
}

(Received 15 November 1977)

\begin{abstract}
The genus Erwinia is heterogeneous with respect to the presence of the ammonia assimilating enzymes glutamine synthetase (GS), NADP-linked glutamate synthase (GOGAT) and NADP-linked glutamate dehydrogenase. Three major groups were distinguished; one showed activity of all three enzymes, the second only GS and GOGAT activity and the third only GS activity. Aspartase did not appear to be significant in ammonia assimilation in any group.
\end{abstract}

\section{INTRODUCTION}

Nitrogen is essential for the growth of micro-organisms and, therefore, an understanding of its assimilation, especially from inorganic sources, is of fundamental importance. Whatever the primary source of nitrogen, ammonia plays a central role in this assimilation. Many pathways for the incorporation of ammonia into organic acceptors have been implicated in bacteria, but two routes are of major importance (Brown, MacdonaldBrown \& Meers, 1974; Brown \& Johnson, 1977). These are the long recognized NADPlinked glutamate dehydrogenase (GDH) and the more recently discovered, energy-dependent coupled system of glutamine synthetase (GS) and NADP- or NAD-linked glutamate synthase (GOGAT). Both pathways result in the net synthesis of one molecule of glutamate from ammonia. The significance of the GS/GOGAT couple lies in its greater efficiency at low ammonia concentrations due to the high affinity of GS for ammonia.

The phytopathogenic genus Erwinia, in its latest classification (Lelliott, 1974), consists of 15 species, grouped into the 'amylovora', 'carotovora' and 'herbicola' clusters; this subdivision is largely based upon acid production in peptone water sugars and a further series of biochemical tests. Phytopathogenic bacteria have, in general, been neglected from a physiological point of view and little data is available concerning ammonia assimilation in Erwinia species. In an organism the identity of which is in doubt, but which is likely to be E. carotovora var. carotovora, GDH was detected although it was suggested that aspartase was probably responsibie for the assimilation of ammonia (Grula et al., 1968). In a strain (MRE 604) of E. carotovora examined by Meers, Tempest \& Brown (1970), NADP-GOGAT activity was present but GDH was not detected.

It was in view of the paucity of data concerning ammonia assimilation in this potentially economically important genus that the present study was undertaken. This communication reports upon a comparative systematic study of the mechanisms of ammonia assimilation, and their control, in representative members of the genus Erwinia grown in batch cultures and in the more physiologically demanding continuous (chemostat) cultures. 


\section{METHODS}

Bacterial strains. The bacteria used in this study were obtained from the National Collection of Plant Pathogenic Bacteria (NCPPB), Harpenden, Hertfordshire, and were as follows (NCPPB numbers given in parentheses). 'Amylovora' cluster: E. amylovora (595), E. salicis (447), E. tracheiphila (2452), E. nigrifluens (564), E. quercina (1852), E. rubrifaciens (2020). 'Herbicola' cluster: E. herbicola var. herbicola (660), E. herbicola var. ananas (441), E. stewartii (449), E. uredovora (1416). 'Carotovora' cluster: E. carotovora var. carotovora (312), E. carotovora var. atroseptica (549), E. chrysanthemi (402), E. cypripedii (750), E. rhapontici (139).

They were maintained by fortnightly subculture on nutrient agar slopes [Lab lemco, $0.8 \%(\mathrm{w} / \mathrm{v})$; peptone, $1.0 \%(\mathrm{w} / \mathrm{v}) ; \mathrm{NaCl}, 0.5 \%(\mathrm{w} / \mathrm{v}) ; \mathrm{Lab} \mathrm{M}$ agar, $2.0 \%(\mathrm{w} / \mathrm{v})$ ] or yeast extract agar slopes [yeast extract, $0.7 \%$ (w/v); peptone, $1.0 \%(\mathrm{w} / \mathrm{v})$; D-glucose, $1.0 \%(\mathrm{w} / \mathrm{v}) ; \mathrm{NaCl}, 0.5 \%(\mathrm{w} / \mathrm{v}) ; \mathrm{Lab} \mathrm{M}$ agar, $2.0 \%(\mathrm{w} / \mathrm{v})]$.

Growth conditions. Defined liquid growth media were adapted from those described by Starr $(1946 a, b$; 1949) and Starr \& Mandel (1950).

Batch cultures. The medium contained (mmol $\mathrm{l}^{-1}$ in distilled water): D-glucose, $14 ; \mathrm{MgSO}_{4} .7 \mathrm{H}_{2} \mathrm{O}, 0.8$; $\mathrm{KH}_{2} \mathrm{PO}_{4}, 15 ; \mathrm{NaCl}, 8 \cdot 6 ; \mathrm{NH}_{4} \mathrm{Cl}$ or $\mathrm{KNO}_{3}$ or Casamino acids (as glutamic acid equivalent), 3.6. It was autoclaved at $115^{\circ} \mathrm{C}$ for $20 \mathrm{~min}$ (D-glucose and $\mathrm{KH}_{2} \mathrm{PO}_{4}$ were autoclaved separately), and then sterile solutions of trace elements and vitamins were added aseptically to give the following final concentrations $\left(\mu \mathrm{mol} \mathrm{l}^{-1}\right): \mathrm{H}_{3} \mathrm{BO}_{3}, 0.081 ; \mathrm{KI}, 0.006 ; \mathrm{CuSO}_{4} .5 \mathrm{H}_{2} \mathrm{O}, 0.036 ; \mathrm{FeSO}_{4} .7 \mathrm{H}_{2} \mathrm{O}, 1 \cdot 3 ; \mathrm{MnSO}_{4} . \mathrm{H}_{2} \mathrm{O}, 0.09 ; \mathrm{MoO}_{3}$, $0.069 ; \mathrm{ZnSO}_{4} .7 \mathrm{H}_{2} \mathrm{O}, 0.17 ; \mathrm{CaCO}_{3}, 100$; thiamin hydrochloride, 0.0089 ; biotin, 0.0045 ; nicotinic acid, 1.6; calcium pantothenate, 0.42 ; riboflavin, 0.13 ; cyanocobalamin, 0.003 ; $p$-aminobenzoic acid, 0.37 ; and folic acid, 0.23 . The final $\mathrm{pH}$ of the medium was 6.8 . Cultures were grown in 1 litre medium in 2 litre Erlenmeyer flasks in an orbital shaker incubator (Gallenkamp) at $30^{\circ} \mathrm{C}$ and $150 \mathrm{rev} . \mathrm{min}^{-1}$.

Continuous cultures. The media contained (mmol $\mathrm{l}^{-1}$ in distilled water): for ammonia-limited conditions, D-glucose, $67 ; \mathrm{MgSO}_{4} .7 \mathrm{H}_{2} \mathrm{O}, 4 \cdot 1 ; \mathrm{NaCl}, 8 \cdot 6 ; \mathrm{KH}_{2} \mathrm{PO}_{4}, 15 ; \mathrm{NH}_{4} \mathrm{Cl}, 7 \cdot 2$; and for ammonia-excess (glucoselimited) conditions, D-glucose, $14 ; \mathrm{MgSO}_{4} .7 \mathrm{H}_{2} \mathrm{O}, 4 \cdot 1 ; \mathrm{NaCl}, 8 \cdot 6 ; \mathrm{KH}_{2} \mathrm{PO}_{4}, 15 ; \mathrm{NH}_{4} \mathrm{Cl}, 36$. The media were autoclaved (D-glucose and $\mathrm{KH}_{2} \mathrm{PO}_{4}$ were autoclaved separately) and trace elements and vitamins were added as described above. Cultures were grown in a Porton-type chemostat of working volume 1 litre at $30{ }^{\circ} \mathrm{C}$ and at a dilution (= growth) rate of $0.05 \mathrm{~h}^{-1} . \mathrm{pH}$ was maintained at 6.8 by the automatic addition of sterile $2 \mathrm{M}$-sodium hydroxide, and the vessel was sparged with sterile air at 1 litre $\mathrm{min}^{-1}$.

Preparation of cell-free (enzyme) extracts. Batch cultures were harvested in the late-exponential phase of growth and chemostat cultures directly from the culture vessel. Samples were centrifuged at $4500 \mathrm{~g}$ for $15 \mathrm{~min}$ at $4^{\circ} \mathrm{C}$, and the pellet was washed once in $100 \mathrm{~mm}$-phosphate buffer $(\mathrm{pH} 7 \cdot 8)$, centrifuged as before, and finally resuspended in a small volume of phosphate buffer containing $1 \mathrm{~mm}$-2-mercaptoethanol.

Bacteria were disrupted using either an ultrasonic disintegrator (MSE) for two $20 \mathrm{~s}$ periods, with intervening cooling, or an X-Press (Biotec, Stockholm, Sweden) for three cycles. Unbroken bacteria and debris were removed by centrifuging at $75000 \mathrm{~g}$ for $30 \mathrm{~min}$ at $4{ }^{\circ} \mathrm{C}$. Low molecular weight metabolites were removed from the resulting extract by passage through a column $(30 \times 2 \mathrm{~cm})$ of Sephadex G-50 at $4{ }^{\circ} \mathrm{C}$. 2-Mercaptoethanol was added to the extract to give a final concentration of $1 \mathrm{~mm}$.

Enzyme assays. Glutamate dehydrogenase [GDH; L-glutamate:NADP + oxidoreductase (deaminating); EC 1.4.1.4] and glutamate synthase [GOGAT; L-glutamine:2-oxoglutarate aminotransferase (NADPHoxidizing); EC 2.6.1.53] were assayed spectrophotometrically by measuring NAD(P)H oxidation at $340 \mathrm{~nm}$. The assay system contained (in $3.0 \mathrm{ml}$ ): $200 \mu \mathrm{mol}$ phosphate buffer (pH 7.8);0.1 $\mu \mathrm{mcl} \mathrm{NAD(P)H;} 10 \mu \mathrm{mol}$ 2-oxoglutarate; and enzyme preparation. The endogenous (non-specific) rate of oxidation was monitored using this mixture, and then either $100 \mu \mathrm{mol} \mathrm{NH} \mathrm{NH}_{4} \mathrm{Cl}$ or $30 \mu \mathrm{mol}$ glutamine (freshly prepared solution) was added to start the reaction and the specific rate of oxidation was measured.

Enzymes analogous to GDH and GOGAT, but using different acceptor molecules, were also assayed by the above method except that one of the following was substituted for the 2-oxoglutarate: $10 \mu$ mol pyruvate; $10 \mu \mathrm{mol}$ oxaloacetate; $10 \mu \mathrm{mol} 2$-oxobutyrate; $40 \mu \mathrm{mol} 2$-oxoisovalerate. Specific activities are expressed as $\mathrm{nmol} \mathrm{NAD}(\mathrm{P}) \mathrm{H}$ oxidized $\mathrm{min}^{-1}$ (mg protein) ${ }^{-1}$.

Glutamine synthetase [GS; L-glutamate:ammonia ligase (ADP-forming); EC 6.3.1.2] was assayed by measuring the formation of $\gamma$-glutamyl hydroxamate at $\mathrm{pH} 7.8$ (imidazole/ $\mathbf{H C l}$ buffer), as described by Elliott (1955). Specific activities are expressed as nmol $\gamma$-glutamyl hydroxamate formed $\mathrm{min}^{-1}(\mathrm{mg} \text { protein })^{-1}$, calibrated against a standard solution of $\gamma$-glutamyl hydroxamate.

Aspartase [L-aspartate ammonia-lyase; EC 4.3.1.1] was assayed using a modification of the method described by Halpern \& Umbarger (1960) and Marcus \& Halpern (1969). The assay system contained (in $3.0 \mathrm{ml}$ ): $200 \mu \mathrm{mol}$ phosphate buffer (pH 7.8); $1 \mu \mathrm{mol} \mathrm{MgSO}_{4} .7 \mathrm{H}_{2} \mathrm{O} ; 40 \mu \mathrm{mol}$ potassium aspartate; and enzyme preparation. The ammonia liberated was estimated by the method of Fawcett \& Scott (1960). Specific activities are expressed as nmol ammonia released $\min ^{-1}$ (mg protein $)^{-1}$. 
Glutaminase [L-glutamine amidohydrolase; EC 3.5.1.2] was assayed in the same way as aspartase except that $\mathrm{MgSO}_{4} \cdot 7 \mathrm{H}_{2} \mathrm{O}$ and potassium aspartate were replaced by $0 \cdot 3 \mu \mathrm{mol}$ EDTA and $30 \mu \mathrm{mol}$ glutamine (freshly prepared solution), respectively.

Protein content. The protein contents of cell-free extracts were determined using the Folin-Ciocalteau reagent as described by Lowry et al. (1951).

\section{RESULTS}

\section{Batch cultures studies}

All members of the genus Erwinia studied grew in defined glucose/salts medium with ammonia as nitrogen source, showing maximum specific growth rates in the range $0 \cdot 17 \mathrm{~h}^{-1}$ to $0.39 \mathrm{~h}^{-1}$. All members of the 'carotovora' cluster utilized nitrate as sole nitrogen source whereas none of the 'amylovora' cluster (except E. tracheiphila) and only some of the 'herbicola' cluster could do so. Casamino acids or glutamate, provided as sole source of nitrogen, supported growth of all species.

The activities of GS, NADP-GOGAT and NADP-GDH in extracts of members of the 'herbicola', 'carotovora' and 'amylovora' clusters, grown with different sources of nitrogen, are shown in Table 1. NAD-GOGAT, NAD-GDH and corresponding amidotransferases and dehydrogenases (both NAD- and NADP-linked) able to utilize pyruvate, oxaloacetate, oxobutyrate, or oxoisovalerate were not detected in any cultures. Although heterogeneity with respect to the presence and activity of enzymes was apparent, the presence of GS was a common feature of all cultures examined. In general, GS activities were higher (up to $60 \%$ ) during growth on Casamino acids than on either nitrate or ammonia.

In members of the 'herbicola' cluster, GS was the only ammonia assimilating enzyme detected. In both the 'carotovora' and 'amylovora' clusters, however, a more complex pattern of enzyme distribution was seen. Both E. carotovora var. carotovora and E. carotovora var. atroseptica possessed GOGAT and GDH, the activities of both enzymes being higher during growth on ammonia than on the other nitrogen sources. In E. chrysanthemi only GOGAT was detected whilst in E. rhapontici only GDH was present (and only during growth on ammonia). Erwinia cypripedii, however, showed only GS activity and was thus similar to species in the 'herbicola' cluster. In the 'amylovora' cluster, the type species, E. amylovora, showed only GS activity; E. salicis, E. nigrifluens, E. quercina and E. rubrifaciens showed GOGAT activity but not GDH; and E. tracheiphila showed both GOGAT and GDH activities.

These findings, which demonstrated the heterogeneity of the genus Erwinia with respect to ammonia assimilating enzymes and, in some species, the apparent absence of a mechanism for the assimilation of ammonia, prompted a more physiologically demanding study employing continuous (chemostat) cultures.

\section{Continuous culture studies}

Cultures were established under two nitrogen nutrient regimes, namely, ammonia limitation and ammonia excess coupled with glucose limitation. It was believed that such an approach would elucidate not only which mechanisms of ammonia assimilation were operative but also the control of their expression. Of the enzymes which had been assayed in batch cultures, only those which had been detected (i.e. GS, NADP-GOGAT and NADP-GDH) were measured in extracts obtained from continuous cultures. In addition, aspartase and glutaminase were assayed, the former because it is a putative ammonia assimilating enzyme and the latter to eliminate the possibility that any observed NADPGOGAT activity might be due to the combined effects of glutaminase and NADP-GDH. In no case could an observed GOGAT activity be ascribed to such combined activities.

All members of the 'herbicola' cluster showed GS activity (Table 2), with much higher activities under ammonia-limited conditions than under ammonia-excess conditions. GOGAT and GDH activities were not detected. Aspartase activity was present except in 
Table 1. Activities of ammonia assimilating enzymes in batch-grown cultures of Erwinia spp.

\section{Organism}

'Herbicola' cluster

E. herbicola var. herbicola

\section{E. herbicola} var. ananas

E. stewartii

E. uredovora

'Carotovora' cluster

E. carotovora var. carotovora

E. carotovora var. atroseptica

E. chrysanthemi

E. cypripedii

E. rhapontici

'Amylovora' cluster E. amylovora

E. salicis

E. tracheiphila

E. nigrifluens

E. quercina

E. rubrifaciens
Nitrogen source*

Nitrate

Ammonia

Casamino acids

Nitrate

Ammonia

Casamino acids

Nitrate

Ammonia

Casamino acids

Nitrate

Ammonia

Casamino acids

Nitrate

Ammonia

Casamino acids

Nitrate

Ammonia

Casamino acids

Nitrate

Ammonia

Casamino acids

Nitrate

Ammonia

Casamino acids

Nitrate

Ammonia

Casamino acids

Nitrate

Ammonia

Casamino acids

Nitrate

Ammonia

Casamino acids

Nitrate

Ammonia

Casamino acids

Nitrate

Ammonia

Casamino acids

Nitrate

Ammonia

Casamino acids

Nitrate

Ammonia

Casamino acids
Specific activity $\dagger$

$\overbrace{\text { GS }}^{\text {NADP- }} \begin{array}{cc}\text { NADP- } \\ \text { GDHA }\end{array}$

NG

ND

ND ND

ND ND

ND ND

ND ND

NG NG

ND ND

ND ND

ND ND

ND ND

ND ND

$8 \quad 11$

$17 \quad 448$

ND 32

$17 \quad 9$

$26 \quad 108$

15 ND

$14 \quad$ ND

$40 \quad \mathrm{ND}$

ND

ND

ND

ND

ND

24

ND

17 ND $\quad$ ND

$\begin{array}{lll}7 & 10 & \text { ND }\end{array}$

$18 \quad 4 \quad$ ND

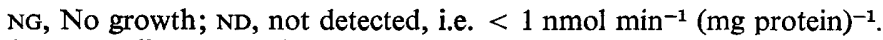

* For media, see Methods.

$\uparrow$ See Methods. 
Table 2. Influence of the concentration of ammonia on the activities of ammonia assimilating enzymes in chemostat cultures of Erwinia spp.

\begin{tabular}{|c|c|c|c|c|c|}
\hline \multirow[b]{2}{*}{ Organism } & \multirow[b]{2}{*}{ Growth condition* } & \multicolumn{4}{|c|}{ Specific activity $\uparrow$} \\
\hline & & GS & $\begin{array}{l}\text { NADP- } \\
\text { GOGAT }\end{array}$ & $\begin{array}{l}\text { NADP- } \\
\text { GDH }\end{array}$ & Asparta \\
\hline $\begin{array}{l}\text { 'Herbicola' cluster } \\
\text { E. herbicola } \\
\text { var. herbicola }\end{array}$ & $\begin{array}{l}\text { Ammonia-limited } \\
\text { Ammonia-excess }\end{array}$ & $\begin{array}{r}34 \\
5\end{array}$ & $\begin{array}{l}\text { ND } \\
\text { ND }\end{array}$ & $\begin{array}{l}\mathrm{ND} \\
\mathrm{ND}\end{array}$ & $\begin{array}{l}\text { ND } \\
411\end{array}$ \\
\hline $\begin{array}{l}\text { E. herbicola } \\
\text { var. ananas }\end{array}$ & $\begin{array}{l}\text { Ammonia-limited } \\
\text { Ammonia-excess }\end{array}$ & $\begin{array}{r}66 \\
7\end{array}$ & $\begin{array}{l}\text { ND } \\
\text { ND }\end{array}$ & $\begin{array}{l}\text { ND } \\
\text { ND }\end{array}$ & $\begin{array}{l}99 \\
71\end{array}$ \\
\hline E. stewartii & $\begin{array}{l}\text { Ammonia-limited } \\
\text { Ammonia-excess }\end{array}$ & $\begin{array}{r}93 \\
5\end{array}$ & $\begin{array}{l}\text { ND } \\
\text { ND }\end{array}$ & $\begin{array}{l}\mathrm{ND} \\
\mathrm{ND}\end{array}$ & $\begin{array}{r}50 \\
446\end{array}$ \\
\hline E. uredovora & $\begin{array}{l}\text { Ammonia-limited } \\
\text { Ammonia-excess }\end{array}$ & $\begin{array}{r}61 \\
5\end{array}$ & $\begin{array}{l}\text { ND } \\
\text { ND }\end{array}$ & $\begin{array}{l}\mathrm{ND} \\
\mathrm{ND}\end{array}$ & $\begin{array}{r}\text { ND } \\
264\end{array}$ \\
\hline $\begin{array}{c}\text { 'Carotovora' cluster } \\
\text { E. carotovora } \\
\text { var. carotovora }\end{array}$ & $\begin{array}{l}\text { Ammonia-limited } \\
\text { Ammonia-excess }\end{array}$ & $\begin{array}{r}59 \\
3\end{array}$ & $\begin{array}{l}48 \\
11\end{array}$ & $\begin{array}{r}7 \\
100\end{array}$ & $\begin{array}{l}15 \\
51\end{array}$ \\
\hline $\begin{array}{l}\text { E. carotovora } \\
\quad \text { var. atroseptica }\end{array}$ & $\begin{array}{l}\text { Ammonia-limited } \\
\text { Ammonia-excess }\end{array}$ & $\begin{array}{r}24 \\
4\end{array}$ & $\begin{array}{c}30 \\
9\end{array}$ & $\begin{array}{l}21 \\
69\end{array}$ & $\begin{array}{l}647 \\
510\end{array}$ \\
\hline E. chrysanthemi & $\begin{array}{l}\text { Ammonia-limited } \\
\text { Ammonia-excess }\end{array}$ & $\begin{array}{r}55 \\
6\end{array}$ & $\begin{array}{r}23 \\
8\end{array}$ & $\begin{array}{l}\text { ND } \\
\text { ND }\end{array}$ & $\begin{array}{r}\text { ND } \\
139\end{array}$ \\
\hline E. cypripedii & $\begin{array}{l}\text { Ammonia-limited } \\
\text { Ammonia-excess }\end{array}$ & $\begin{array}{l}6 \\
1\end{array}$ & $\begin{array}{l}\text { ND } \\
\text { ND }\end{array}$ & $\begin{array}{l}\text { ND } \\
\text { ND }\end{array}$ & $\begin{array}{l}363 \\
275\end{array}$ \\
\hline E. rhapontici & $\begin{array}{l}\text { Ammonia-limited } \\
\text { Ammonia-excess }\end{array}$ & $\begin{array}{r}49 \\
5\end{array}$ & $\begin{array}{l}\text { ND } \\
\text { ND }\end{array}$ & $\begin{array}{r}3 \\
13\end{array}$ & $\begin{array}{l}\text { ND } \\
\text { ND }\end{array}$ \\
\hline $\begin{array}{c}\text { 'Amylovora' cluster } \\
\text { E. amylovora }\end{array}$ & $\begin{array}{l}\text { Ammonia-limited } \\
\text { Ammonia-excess }\end{array}$ & $\begin{array}{l}92 \\
11\end{array}$ & $\begin{array}{l}\mathrm{ND} \\
\mathrm{ND}\end{array}$ & $\begin{array}{l}\text { ND } \\
\text { ND }\end{array}$ & $\begin{array}{r}12 \\
110\end{array}$ \\
\hline E. salicis & $\begin{array}{l}\text { Ammonia-limited } \\
\text { Ammonia-excess }\end{array}$ & $\begin{array}{l}36 \\
10\end{array}$ & $\begin{array}{l}9 \\
9\end{array}$ & $\begin{array}{l}\text { ND } \\
\text { ND }\end{array}$ & $\begin{array}{l}\text { ND } \\
74\end{array}$ \\
\hline E. nigrifluens & $\begin{array}{l}\text { Ammonia-limited } \\
\text { Ammonia-excess }\end{array}$ & $\begin{array}{r}92 \\
3\end{array}$ & $\begin{array}{l}41 \\
24\end{array}$ & $\begin{array}{l}\text { ND } \\
\text { ND }\end{array}$ & $\begin{array}{l}319 \\
105\end{array}$ \\
\hline E. quercina & $\begin{array}{l}\text { Ammonia-limited } \\
\text { Ammonia-excess }\end{array}$ & $\begin{array}{r}60 \\
8\end{array}$ & $\begin{array}{r}38 \\
8\end{array}$ & $\begin{array}{l}\text { ND } \\
\text { ND }\end{array}$ & $\begin{array}{l}\mathrm{ND} \\
\mathrm{ND}\end{array}$ \\
\hline E. rubrifaciens & $\begin{array}{l}\text { Ammonia-limited } \\
\text { Ammonia-excess }\end{array}$ & $\begin{array}{l}46 \\
11\end{array}$ & $\begin{array}{r}15 \\
6\end{array}$ & $\begin{array}{l}\text { ND } \\
\text { ND }\end{array}$ & $\begin{array}{l}\text { ND } \\
\text { ND }\end{array}$ \\
\hline
\end{tabular}

$\mathrm{ND}$, Not detected, i.e. $<1 \mathrm{nmol} \mathrm{min}^{-1}(\mathrm{mg} \text { protein) })^{-1}$.

* For media, see Methods.

$\dagger$ See Methods.

ammonia-limited cultures of E. herbicola var. herbicola and E. uredovora and was generally greater when ammonia was provided in excess.

GS activity was also present in all members of the 'carotovora' cluster (Table 2) and, again, activities were higher under conditions of ammonia-limited growth. As previously observed in batch-grown cultures with ammonia (Table 1), E. carotovora var. carotovora and var. atroseptica showed activities of both GOGAT and GDH. Reciprocal control of these enzymes appeared to operate in that high GOGAT/low GDH levels were obtained under ammonia-limited conditions whilst the reverse was true when ammonia was present in excess. In E. chrysanthemi only GOGAT activity was present and showed similar control to that seen in strains of E. carotovora, whilst in E. rhapontici GDH was present and at a higher level under conditions of ammonia excess. Erwinia cypripedii, however, showed neither GOGAT nor GDH activity thus confirming the batch culture results. Aspartase activity was detected in all organisms of this cluster except $E$. rhapontici, but no real pattern was apparent. 
Members of the 'amylovora' cluster (Table 2) all showed GS activity with a similar pattern of control. Again, as observed in batch cultures (Table 1), E. amylovora showed no activity of either GOGAT or GDH whilst the other members of the group showed only GOGAT activity with higher levels being observed under conditions of ammonia limitation. Aspartase activity was only detected in E. amylovora, E. salicis and E. nigrifluens.

\section{DISCUSSION}

The present study has established that the genus Erwinia is heterogeneous with respect to the mechanisms of ammonia assimilation and, further, that such heterogeneity exists within the individual 'carotovora' and 'amylovora' clusters. The erwinias can be broadly divided into three groups with respect to the presence of the recognized ammonia assimilating enzymes GS, GOGAT and GDH.

The first group comprises organisms like E. carotovora which assimilate ammonia by either the GS/GOGAT or GDH routes depending upon the ammonia concentration in the medium. Reciprocal control of these pathways is operative in that under conditions of ammonia limitation GS and GOGAT activities are high and that of GDH is low, whilst under conditions of ammonia excess the reverse is true. Although this behaviour is typical of that previously reported for several bacteria, e.g. Klebsiella (Aerobacter) aerogenes (Meers et al., 1970; Brenchley, Prival \& Magasanik, 1973), it differs from that reported for E. carotovora MRE 604 in which GDH activity was not detected (Meers et al., 1970). Such reciprocal control makes metabolic sense in an organism which may, in its natural environment, be exposed to fluctuating concentrations of ammonia.

The second group comprises organisms such as E. salicis, E. nigrifluens, E. quercina and E. rubrifaciens which apparently assimilate ammonia only by the GS/GOGAT route. These enzymes appear to be controlled in a fashion similar to that in E. carotovora, showing decreased activities under conditions of ammonia excess. In the absence of GDH, such behaviour raises questions as to the significance of the GS/GOGAT route under conditions of ammonia excess. The possession of this single high affinity pathway might indicate that, under natural conditions, these organisms normally only encounter low concentrations of ammonia and that under high concentrations of ammonia, efficiency of growth is reduced. Alternatively, some other undetected low affinity pathway may replace GDH when ammonia concentrations are high.

The third group, which includes E. amylovora, E. cypripedii and the 'herbicola' cluster, shows only GS activity. Since GS alone cannot account for the net assimilation of ammonia, an alternative route must operate. It has been suggested that aspartase may be responsible for ammonia assimilation in Erwinia sp. (Grula et al., 1968), but, from studies on Escherichia coli, the biosynthetic role of aspartase is in doubt (Halpern \& Umbarger, 1960; Vender \& Rickenberg, 1964; Vender, Jayaraman \& Rickenberg, 1965; Marcus \& Halpern, 1969). This, taken with the view of Tosa et al. (1977) that the enzyme in Escherichia coli may be membrane-bound, and the present findings that (i) aspartase activities in GOGAT/GDH negative organisms are not substantially different from those in GOGAT/GDH positive organisms, and (ii) aspartase activities are generally decreased under ammonia-limited growth conditions, suggest that the primary function of aspartase is catabolic. Thus, in the third group of erwinias, a hitherto unrecognized pathway of ammonia assimilation may exist. Further studies are being undertaken to investigate this possibility.

The one enzyme consistently detected in all cultures was GS, which is perhaps not surprising in view of the multiple biosynthetic requirements for glutamine. The control of synthesis of this enzyme was similar in all species examined. The relatively high level of GS in cultures grown in the presence of amino acids agrees well with the suggestions that amino acids, provided as sole nitrogen source, produce conditions of nitrogen limitation (Mecke \& Holzer, 1966; Woolfolk, Shapiro \& Stadtman, 1966) and that glutamate can act 
as an inducer of GS synthesis (Wu \& Yuan, 1968). The consistently observed derepression of GS synthesis upon transfer from ammonia-excess to ammonia-limited conditions is in keeping with previous findings in many bacteria (Meers et al., 1970; Shapiro \& Stadtman, 1970; Brenchley et al., 1973; Brown et al., 1974).

In conclusion, the present study has shown a complex pattern with respect to ammonia assimilating enzymes in the genus Erwinia. Some members are like many other bacteria in that they possess GS and either GOGAT or GDH or both, whilst in other members there was no detectable pathway of ammonia assimilation. Findings such as these stress the need for more systematic approaches in studies of this type rather than restricting attention to a single 'representative' species.

One of us (D.P.) is grateful to the Science Research Council for the award of a postgraduate research studentship.

\section{REFERENCES}

Brenchley, J. E., Prival, M. J. \& Magasanik, B. (1973). Regulation of the synthesis of enzymes responsible for glutamate formation in Klebsiella aerogenes. Journal of Biological Chemistry 248, 6122-6128.

Brown, C. M. \& Johnson, B. (1977). Inorganic nitrogen assimilation in aquatic micro-organisms. In Advances in Aquatic Microbiology, vol. 1, pp. 49-114. Edited by M. R. Droop and H. W. Jannasch. Academic Press: London.

Brown, C. M., Macdonald-Brown, D.S. \& Meers, J. L. (1974). Physiological aspects of microbial inorganic nitrogen metabolism. $A d-$ vances in Microbial Physiology 11, 1-52.

ElliotT, W. H. (1955). Glutamine synthesis. Methods in Enzymology 2, 337-342.

FAwCETT, J. K. \& SCOTT, J. E. (1960). A rapid and precise method for the determination of urea. Journal of Clinical Pathology 13, 156-159.

Grula, M. M., Smith, R. W., Parham, C. F. \& Grula, E. A. (1968). Cell division in a species of Erwinia. XI. Some aspects of the carbon and nitrogen nutrition of Erwinia species. Canadian Journal of Microbiology 14, 1217-1224.

Halpern, Y. S. \& UMbarger, H. E. (1960). Conversion of ammonia to amino groups in Escherichia coli. Journal of Bacteriology 80, 285-288.

LelliotT, R. A. (1974). Erwinia Winslow, Broadhurst, Buchanan, Krumwiede, Rogers and Smith 1920, 209. In Bergey's Manual of Determinative Bacteriology, 8th edn, pp. 332-340. Edited by R. E. Buchanan and N. E. Gibbons. Baltimore: Williams \& Wilkins.

Lowry, O. H., Rosebrough, N. J., Farr, A. L. \& RANDALL, R. J. (1951). Protein measurement with the Folin phenol reagent. Journal of Biological Chemistry 193, 265-275.

Marcus, M. \& Halpern, Y.S. (1969). The metabolic pathway of glutamate in Escherichia coli K-12. Biochimica et biophysica acta 177, 314-320.

MeCKe, D. \& Holzer, H. (1966). Repression and inactivation of glutamine synthetase in Escherichia coli by ammonium. Biochimica et biophysica acta 122, 341-351.
Meers, J. L., Tempest, D. W. \& Brown, C. M. (1970). 'Glutamine(amide): 2-oxoglutarate amino transferase oxido-reductase (NADP)', an enzyme involved in the synthesis of glutamate by some bacteria. Journal of General Microbiology 64, 187-194.

Shapiro, B. M. \& Stadtman, E. R. (1970). Regulation of glutamine synthesis in micro-organisms. Annual Review of Microbiology 24, 501-524.

STARR, M. P. (1946a). The nutrition of phytopathogenic bacteria. I. Minimal nutritive requirements of the genus Xanthomonas. Journal of Bacteriology 51, 131-143.

Starr, M. P. (1946b). The nutrition of phytopathogenic bacteria. II. The genus Agrobacterium. Journal of Bacteriology 52, 187-193.

STARR, M.P. (1949). The nutrition of phytopathogenic bacteria. III. The gram-positive phytopathogenic Corynebacterium species. Journal of Bacteriology 57, 253-258.

Starr, M. P. \& Mandel, M. (1950). The nutrition of the phytopathogenic bacteria. IV. Minimal nutritive requirements of the genus Erwinia. Journal of Bacteriology 60, 669-672.

Tosa, T., Sato, T., Nishida, Y. \& Chibata, I. (1977). Reason for higher stability of aspartase activity of immobilised Escherichia coli cells. Biochimica et biophysica acta 483, 193-202.

VENDER, J. \& RickenBerG, H. V. (1964). Ammonia metabolism in a mutant of Escherichia coli lacking glutamate dehydrogenase. Biochimica et biophysica acta 90, 218-220.

Vender, J., Jayaraman, K. \& Rickenberg, H. V. (1965). Metabolism of glutamic acid in a mutant of Escherichia coli. Journal of Bacteriology 90, 1304-1307.

Woolfolk, C. A., Shapiro, B. \& Stadtman, E. R. (1966). Regulation of glutamine synthetase. I. Purification and properties of glutamine synthetase from Escherichia coli. Archives of Biochemistry and Biophysics 116, 177-192.

Wu, C. \& YuaN, L. H. (1968). Regulation of synthesis of glutamine synthetase in Escherichia coli. Journal of General Microbiology 51, 57-65. 